\title{
Analisis Potensi Sektor Unggulan dan Pemetaan Kemiskinan Masyarakat di Wilayah Maminasata Sulawesi Selatan
}

\author{
Citra Ayni Kamaruddin ${ }^{1}$, Syamsu Alam² \\ Universitas Negeri Makassar \\ Email: citra7172@gmail.com, alam.s@unm.ac.id
}

(Diterima: 12-Maret-2018; di revisi: 17-April-2018; dipublikasikan: 30-Juni-2018)

\begin{abstract}
ABSTRAK
Tujuan penelitian ini adalah untuk memetakan potensi unggulan sektoral dan perubahan tingkat kemiskinan daerah di wilayah Mamminasata. Metode yang digunakan dalam penelitian ini bersifat kualitatif deskriptif, dengan menggunakan alat analisis kuantitatif, alat analisis sektor unggulan seperti Location Quotient (LQ), Model Rasio Pertumbuhan (MRP), Analisis Overlay, dan Tipologi Klassen. Hasil penelitian meunjukkan bahwa masih tingginya disparitas sektor unggulan di Wilayah Mamminasata. Hasil analisis menunjukkan bahwa Kota Makassar memiliki 12 sektor unggulan, Kab. Gowa, 7 sektor unggulan, Kab. Maros 4 sektor unggulan, dan Kab. Takalar 3 sektor unggulan. Sedangkan hasil analisi Tipologi Klassen menunjukkan hanya Kota Makassar yang konsisten menjukkan 12 sektor yang unggul berada di kuadran I (sektor maju dan tumbuh cepat). Sedangkan Kabupaten lainnya hanya 3 sektor yang berada di kuadran I, sektor ekonomi lainnya bertumbuh tapi tertekan, ada juga yang potensial. Bahkan, Kab Maros dan Kab. Takalar memiliki 11 sektor yang masih tertinggal. Berdasarkan pemetaan kemiskinan Kab/kota di wilayah Mamminasata menunjukkan bahwa Kota Makassar dan Kab. Gowa memiliki rata-rata jumlah penduduk miskin lebih rendah daripada Provinsi Sulawesi Selatan. Kabupaten Takalar cenderung sama dengan provinsi Sulawesi Selatan, dan ada gejala paradoksal antara Laju PDRB dan kemiskinan. Sedangkan Kab. Maros di atas rata-rata kemiskinan Prov. Sulsel. Secara aggregat kemiskinan di Wilayah Mamminasata menurun selama periode penelitian. Kota Makassar, Kab. Gowa, Kab. Maros, meskipun Laju pertumbuhannya menurun, jumlah warga miskinnya juga menurun. Sedangkan Kabupaten Takalar laju PDRBnya meningkat namun kemiskinannya juga meningkat.
\end{abstract}

Kata Kunci: Sektor Unggulan, Pemetaan Kemiskinan, Kemiskinan

\begin{abstract}
The purpose of this study is to map sectoral superior potential and changes in regional poverty levels in the Mamminasata region. The method used in this study is qualitative descriptive, using quantitative analysis tools, leading sector analysis tools such as Location Quotient (LQ), Growth Ratio Model (MRP), Overlay Analysis, and Klassen Typology. The results of the study show that there is still a high level of disparity in leading sectors in the Mamminasata region. The results of the analysis show that Makassar City has 12 leading sectors, Kab. Gowa, 7 leading sectors, Maros District 4 leading sector, and Takalar District 3 superior sector. While the results of the Klassen Typology analysis show that only Makassar City consistently shows 12 superior sectors in quadrant I (advanced and fast-growing sectors). While other regencies are only 3 sectors which are in quadrant I, other economic sectors are growing but depressed, there are also potential ones. In fact, Maros Regency and District. Takalar has 11 sectors that are still lagging behind. Based on the poverty mapping of districts / cities in the Mamminasata area, it shows that Makassar City and District. Gowa has an average number of poor people lower than South Sulawesi Province. Takalar Regency tends to be the same as South Sulawesi province, and there are
\end{abstract}




\author{
86 Jurnal Administrare: Jurnal Pemikiran Ilmiah dan Pendidikan Administrasi Perkantoran \\ Vol. 5, No. 2, Juli - Desember 2018, Hal 85-98
}

paradoxical symptoms between GDP and poverty. Whereas Kab. Maros is above the poverty average of Prov. South Sulawesi. In aggregate poverty in the Mamminasata area declined during the study period. Makassar City, Kab. Gowa, Kab. Maros, even though the rate of growth declined, the number of poor people also declined. Whereas Takalar Regency has increased GDP but its poverty has also increased.

Keywords: Leading Sector, Mapping Poverty, Poverty

\title{
PENDAHULUAN
}

Kemiskinan masih menjadi isu sekaligus potret ketimpangan global antara negera-negara kaya dan miskin, desa-kota (Nisbett, 2017; Soyinka \& Siu, 2017; Stan, 2015; Zaman \& Khilji, 2013). Untuk menyelesaikan masalah kemiskinan terlebih dahulu perlu diselesaikan seluruh masalah pada tingkat di bawahnya, seperti masalah pendidikan, kesehatan, ketersediaan pangan dan nutrisi, air bersih dan sanitasi, dan lain-lain. Pengembangan wilayah Metropolitan Mamminasata dapat diarahkan sebagai pusat kegiatan nasional yang mendorong pertumbuhan kota-kota disekitarnya sebagai sentra produksi wilayah pulau serta sebagai pusat orientasi pelayanan berskala internasional dan penggerak utama bagi Kawasan Timur Indonesia (Bappenas, 2014).

Beberapa isu strategis lainnya adalah, keterbatasan persebaran pusat pertumbuhan dan konektivitas antara kota atau pusat pertumbuhan yang menyediakan pelayanan ekonomi dan sosial dengan desa-desa di sekitarnya (Chen, Acey, \& Lara, 2015; Hao, Sliuzas, \& Geertman, 2011; Johnson \& Koyama, 2017; Lim, Hassan, Ghaffarianhoseini, \& Daud, 2017). Masih rendahnya keterkaitan antarsektor dari hulu ke hilir yang dapat menciptakan diversifikasi kegiatan ekonomi di perdesaan serta memperkuat hubungan ekonomi antara kota dan desa; Belum optimalnya kerjasama antardaerah yang dapat mendorong terjadinya peningkatan keterkaitan antara desa-kota dan antar daerah administrasi.

Pengembangan wilayah diupayakan untuk mengatasi tiga masalah utama pembangunan yaitu kemiskinan, pengangguran, dan ketimpangan (Anwar \& Sun, 2012; Barberia \& Biderman, 2010; Mohanty, Gurpur, \& Beerannavar, 2014; Timár \& Velkey, 2016; Wu \& Song, 2014). Pembangunan wilayah atau pengembangan kawasan baru perkotaan dapat dilakukan dengan membentuk beberapa Kawasan Strategis Nasional (KSN) menjadi strategi untuk mempercepat pembangunan ekonomi nasional. Pembangunan Wilayah Perkotaan Mamminasata merupakan salah satu strategi untuk mengkondisikan terwujudnya percepatan pembangunan ekonomi melalui penyatuan wilayah perkotaan yang terdiri atas Kota Makassar sebagai wilayah perkotaan inti, Kabupaten Maros, Sungguminasa, dan Takalar sebagai wilayah perkotaan di sekitarnya yang membentuk wilayah metropolitan megapolitan.

Pertumbuhan ekonomi Kota Makassar selama periode 2012-2016 mengalami fluktuasi dan cenderung menurun. Hal yang sama juga terjadi pada Kab. Maros selama periode 20122016 mengalami fluktuasi dan cenderung menurun. Kab. Gowa selama periode 2012-2016 menunjukkan berfluktuasi dan cenderung menurun. Penurunan secara berturut-turut terjadi pada tahun 2014 dan 2015. Sedangkan jumlah penduduk miskin Kab. Gowa selama periode 20122016 mengalami peningkatan yang berkisar 6200 jiwa atau meningkat sekitar $10 \%$ selama 
Citra Ayni Kamaruddin, Syamsu Alam; Analisis Potensi Sektor Unggulan Pemetaan..... 87

2012-1016. Peningkatan jumlah penduduk miskin yang cukup signifikan terjadi pada tahun 2013. Tren pertumbuhan ekonomi Kab. Takalar selama 2012-2016 mengalami fluktuasi dan cenderung mengalami peningkatan. Penurunan pertumbuhan ekonomi di Kab. Takalar hanya terjadi pada tahun 2015. Tetapi angka pertumbuhan ekonomi Kab. Takalar dibawah angka pertumbuhan ekonomi Sulawesi Selatan. Sedangkan jumlah penduduk miskin Kab. Takalar selama 2011-2016 mengalami peningkatan sebesar 2\%. Peningkatan terbesar terjadi pada tahun 2013 yang mengalami peningkatan sebesar $11 \%$.

Pertumbuhan ekonomi atau perubahan PDRB merupakan syarat penting (necessary condition) dalam pembangunan, dan penurunan kemiskinan sebagai syarat cukup (Sufficient condition). Wilayah Maminasata sebagai wilayah pengembangan kota metropolitan. Wilayah Metropolitan Mamminasata, atau juga disebut Metropolitan Mamminasata, meliputi Kota Makassar, Kabupaten Maros, Gowa dan Takalar dibentuk berdasarkan SK Gubernur Provinsi Sulawesi Selatan Tahun 2003. Mamminasata sebagai Pusat Logistik dan Perdagangan di Wilayah Timur Indonesia. Agar berfungsi sebagai pusat yang efektif, Wilayah Mamminasata harus mengembangkan sektor perdagangan dan manufakturnya secara bersamaan dan dikoordinasikan dengan baik. Jika sektor manufaktur dikembangkan di Wilayah Mamminasata dalam tingkatan tertentu, maka bahan baku yang berasal dari Kalimantan, Papua dan pulaupulau lainnya di Kawasan Timur Indonesia dapat diolah dan dirakit di wilayah Mamminasata. Melalui proses penambahan nilai seperti itu, nilai ekonomi yang lebih tinggi akan dihasilkan di Wilayah Mamminasata (JICA \& PU, 2006).

Dalam konteks pembangunan, pandangan terhadap penduduk terbagi dua, ada yang menganggapnya sebagai penghambat pembangunan, ada pula yang menganggap sebagai pemacu pembangunan .Jumlah penduduk dalam pembangunan ekonomi suatu daerah merupakan permasalahan mendasar. Karena pertumbuhan penduduk yang tidak terkendali dapat mengakibatkan tidak tercapainya tujuan pembangunan ekonomi yaitu kesejahteraan rakyat serta menekan angka kemiskinan. Jumlah penduduk yang besar memang merupakan potensi yang besar. Menurut Adam Smith pertumbuhan penduduk mampu mendorong pertumbuhan ekonomi. Penduduk dipandang dari sisi ketenagakerjaan merupakan suplai bagi pasar tenaga kerja di suatu wilayah. Jika pertumbuhan penduduk dan kualitas sumber daya manusia tidak mendapat perhatian dari pemerintah, dapat mengakibatkan laju pertumbuhan penduduk yang tidak terkontrol. Ini dikhawatirkan menambah jumlah pengangguran dan menambah jumlah penduduk miskin.

Pembangunan dan pengembangan Wilayah Metropolitan sebagai upaya untuk meningkatkan produktivitas dan konektivitas antar wilayah dengan tujuan untuk mensejahteraan masyarakat. Berkaitan dengan hal tersebut, pengembangan wilayah seharusnya memastikan bahwa masyarakat dalam wilayah tersebut dapat mengakses pembangunan sekaligus dapat mengoptimalkan aset yang dimiliki oleh warga masmyarakat dalam wilayah metropolitan tersebut.

\section{METODE}

\section{Jenis dan Sumber Data}

Data yang digunakan pada penelitian adalah data sekunder. Data Sekunder bersumber dari Badan Pusat Statistik (BPS) Sulawesi Selatan dan Bappenas. Data yang dikumpulkan 


\section{Jurnal Administrare: Jurnal Pemikiran Ilmiah dan Pendidikan Administrasi Perkantoran} Vol. 5, No. 2, Juli - Desember 2018, Hal 85-98

dalam penelitian ini, yaitu: data PDRB, Data Kemiskinan Kab/Kota di Wilayah Mamminasata serta data penunjang penelitian lainnya.

\section{Definisi Operasional}

Definisi operasional diperlukan untuk menghindari multitafsir atas tentang variabelvariabel yang digunakan, maka dalam penelitian ini memberi batasan defenisi operasional variabel sebagai berikut:

1. Potensi Sektor Perekonomian adalah sektor-sektor yang memiliki potensi/ keunggulan pada suatu wilayah, dimana laju pertumbuhan PDRB Kabupaten/Kota di Mamminasata lebih cepat daripada laju pertumbuhan PDRB Provinsi Sulawesi Selatan dengan diukur menggunakan analisis Location Question $(L Q)$ dengan nilai LQ>1, Model Rasio Pertumbuhan (MRP) dengan nilai RPR (+) dan RPS (+) dan analisis Overlay dengan nilai sektor $(+)$ serta Tipologi Klassen berada pada kuadran I.

2. Produk Domestik Regional Bruto (PDRB) yang menggunakan Pendekatan Produksi (Production Approach) dengan 17 sektor ekonomi yaitu total produksi barang dan jasa yang dihasilkan oleh unit produksi di Kabupaten/Kota di Mamminasata dalam jangka waktu tertentu yaitu satu tahun.

3. Sektor Ekonomi adalah unit lapangan usaha yang ada dalam Produk Domestik Regional Bruto yang dikelompokkan menjadi 17 (tujuh belas) sektor ekonomi dalam PDRB seri 2010.

4. Kemiskinan adalah jumlah penduduk miskin berdasarkan indeks daya beli yang kriterianya ditentukan oleh BPS (Jumlah Jiwa).

\section{Teknik analisis Data}

Metode yang digunakan dalam penelitian ini adalah: (1) metode tabulasi, yaitu melakukan tabulasi datayang diperoleh dari berbagai sumber (2) menganalisis data untuk menjawab permasalahan penelitian.

Adapun rancangan analisis penelitian ini dikemukakan sebagai berikut:

\section{Analisis Location Quotient (LQ)}

Analisis LQ mengukur konsentrasi dari suatu Sektor ekonomi dalam suatu daerah dengan cara membandingkan peranannya dalam perekonomian daerahtersebut dengan peranan kegiatan ekonomi sejenis pada lingkup yang lebih luas (provinsi atau nasional). Secara matematis rumus LQ sebagai berikut:

\section{Keterangan:}

$$
L Q=\frac{X i s / X s}{Y i / Y p}
$$

Xis : Nilai Tambah sektor i di daerah s (Kabupaten Kota di Mamminasata)

Xs : Total nilai tambah sektor i di daerah s

Yi : Nilai tambah sektor i di daerah p (Provinsi Sulawesi Selatan) 
Yp : Total nilai tambah sektor i di daerah $\mathrm{p}$

Setelah dihitung, maka hasil LQ tersebut dapat diinterpretasikan. Berdasarkan formulasi persamaan di atas maka kriteria pengukuran ada tiga kemungkinan yang terjadiyaitu: LQ $>1$; $\mathrm{LQ}=1 ; \mathrm{LQ}<1$

\section{Analisis Model Rasio Pertumbuhan (MRP)}

Model Rasio Pertumbuhan (MRp) merupakan alat analisis alternatif yang dapat digunakan dalam perencanaan wilayah dan kota yang diperoleh dengan memodifikasi model analisis shift and share. Analisis MRP ini dibagi lagi ke dalam dua kriteria, yaitu Rasio Pertumbuhan Wilayah Studi (RPs) dan Rasio Pertumbuhan Wilayah Referensi (RPr).

Berikut ini penjelasan dari masing-masing kriteria MRP:

1. Rasio pertumbuhan wilayah referensi (RPr).

Dalam hal ini RPR membandingkan pertumbuhan masing-masing sektor dalam konteks provinsi dengan PDRB kabupaten/kota.

$R P r=\frac{\Delta \mathrm{EiR} / \mathrm{EiR}}{\Delta \mathrm{ER} / \mathrm{ER}}$

Keterangan:

$\triangle$ Ei R : Perubahan PDRB sektor i di wilayah referensi.

$\triangle E R \quad$ : Perubahan PDRB di wilayah referensi.

EiR : PDRB sektor i di wilayah referensi

ER : PDRB di wilayah referensi

2. Rasio Pertumbuhan Wilayah Studi (RPS)

Dalam hal ini RPS membandingkan pertumbuhan masing-masing sektor dalam konteks kabupaten/kota dengan pertumbuhan sektor provinsi.

$R P_{S}=\frac{\Delta \mathrm{Eij} / \mathrm{Eij}}{\Delta \mathrm{Eij} / \mathrm{EJ}}$

Keterangan:

$\triangle E$ Ei J : Perubahan PDRB sektor i di wilayah studi

$\triangle E J \quad$ : Perubahan PDRB di wilayah studi

EiJ $\quad$ : PDRB sektor i di wilayah studi

EJ $\quad$ : PDRB di wilayah studi

\section{Analisis Overlay}

Analisis ini merupakan penggabungan hasil analisis LQ dan analisis MRP untuk digunakan mengidentifikasi sektor unggul baik dari segi kontribusi maupun pertumbuhannya. Sehingga analisis ini terdiri dari tiga kompenen yaitu Location Quotient (LQ), Rasio Pertumbuhan Wilayah Referensi (RPr) dan Rasio Pertumbuhan Wilayah Studi (RPs).

Dengan metode ini setiap komponen kemudian disamakan satuannya, dengan jalan memberikan penilaian sektor-sektor ekonomi melihat kepada nilai positif (+) dan nilai negtif (-). Jika koefisien komponen bernilai lebih dari satu diberi notasi positif $(+)$ dan jika koefisien komponen bernilai kurang dari satu diberi notasi negatif (-).

Sektor-sektor yang mempunyai jumlah nilai positif (+) paling banyak berarti sektor tesebut merupakan sektor unggulan dan jika nilai suatu sektor mempunyai nilai negatif (-) 


\section{Jurnal Administrare: Jurnal Pemikiran Ilmiah dan Pendidikan Administrasi Perkantoran Vol. 5, No. 2, Juli - Desember 2018, Hal 85-98}

paling banyak atau tidak mempunyai nilai positif sama sekali berarti sektor tersebut bukan merupakan sektor unggulan.

\section{Tipologi Klassen}

Kemajuan dan pertumbuhan ekonomi setiap wilayah tentunya masing-masing berbeda. Ada wilayah yang mampu memacu kegiatan ekonominya sehingga dapat tumbuh pesat. Di sisi lain ada pula wilayah yang tak dapat berbuat banyak sehingga siklus ekonominya stagnan di satu titik atau bahkan tumbuh negatif. Untuk dapat membandingkan tingkat kemajuan suatu wilayah dengan wilayah lain dalam suatu lingkup referensi yang sama, maka dapat digunakan Tipologi Klassen sebagai alat analisis.

Berikut klasifikasi daerah menurut Tipologi Klassen:

\begin{tabular}{|c|c|}
\hline $\begin{array}{c}\text { Kuadran I } \\
\text { Yi }>\text { Ydan Ri }>\text { R } \\
\text { Daerah Cepat Maju dan Cepat Tumbuh }\end{array}$ & $\begin{array}{c}\text { Kuadran II } \\
\text { Yi }>\text { Y dan Ri }<\text { R } \\
\text { Daerah Maju tapi Tertekan }\end{array}$ \\
\hline Kuadran III & $\begin{array}{c}\text { Kuadran IV } \\
\text { Yi }<\text { Y dan Ri }<\text { R } \\
\text { Daerah Relatif Tertinggal } \\
\text { Daerah Berkembang Cepat }\end{array}$ \\
\hline
\end{tabular}

Keterangan:

\section{Gambar 1 Klasifikasi Tipologi Klassen}

$\mathrm{R}_{\mathrm{i}}$ : Laju pertumbuhan ekonomi wilayah i

$\mathrm{Y}_{\mathrm{i}}$ : PDRB perkapita wilayah $\mathrm{i}$

$\mathrm{R}$ : Laju pertumbuhan ekonomi wilayah referensi

Y : PDRB perkapita wilayah referensi

Dengan analisis ini dapat ditentukan tipologi masing-masing sektor sehingga dapat digunakan sebagai acuan pendukung untuk menentukan prioritas dalam pengembangan daerah

\section{HASIL PENELITIAN DAN PEMBAHASAN}

\section{Hasil}

Penelitian ini bertujuan untuk melihat secara empiris berdasarkan data akan dipetakan potensi sektor ekonomi yang unggulan dan pemetaan kemiskinan di kawasan Mamminasata. 


\section{Potensi Sektor Unggulan}

\section{a. Analisis Location Quotient (LQ)}

Setelah mentabulasi data PDRB Kabupaten/kota yang ada di Kawasan Maminasata, maka hasil perhitungan dengan metode LQ menunjukkan bahwa sejak tahun 2012 sampai tahun 2016 sektor perekonomian tidak mengalami perubahan yang berarti. Sektor basis cenderung tetap tidak ada sektor yang mengalami perubahan dari sektor non basis ke sektor basis demikian pula sebaliknya.

\section{Tabel 1}

Hasil Analisis Location Quotient (LQ) di Kabupaten/Kota di Kawasan Maminasata Prov. Sulawesi Selatan 2012-2016

\begin{tabular}{|l|lc|c|c|c|}
\hline \multirow{2}{*}{$\begin{array}{l}\text { Kate } \\
\text { gori }\end{array}$} & \multicolumn{1}{|c|}{ Lapangan Usaha } & \multicolumn{4}{c|}{ PDRB 2012-2016 } \\
\cline { 3 - 6 } & & Makassar & Gowa & Maros & Takalar \\
\hline A & Pertanian, Kehutanan, dan Perikanan & 0.03 & 1.44 & 0.79 & 2.15 \\
B & Pertambangan dan Penggalian & 0.00 & 0.45 & 1.16 & 0.25 \\
D & Industri Pengolahan & 1.43 & 0.45 & 1.55 & 0.44 \\
E & Pengadaan Listrik, Gas & 0.34 & 1.98 & 0.90 & 1.82 \\
F & Pengadaan Air & 1.87 & 1.12 & 0.80 & 0.46 \\
& Konstruksi & 1.41 & 0.88 & 0.47 & 0.60 \\
G & Perdagangan Besar dan Eceran, dan & & & & \\
H & Tranarasi Mobil dan Sepeda Motor & 1.34 & 0.83 & 0.24 & 0.96 \\
& Penyediaan Akomodasi dan Makan & 0.68 & 0.40 & 8.90 & 0.82 \\
I & Minum & 1.73 & 1.78 & 0.25 & 0.25 \\
J & Informasi dan Komunikasi & 1.53 & 1.64 & 0.23 & 0.65 \\
K & Jasa Keuangan & 1.73 & 0.67 & 0.41 & 0.38 \\
L & Real Estate & 1.13 & 2.04 & 0.41 & 1.66 \\
M,N & Jasa Perusahaan & 2.72 & 0.28 & 0.06 & 0.02 \\
& Administrasi Pemerintahan, & & & & \\
O & Pertahanan dan Jaminan Sosial Wajib & 0.76 & 1.22 & 0.82 & 1.54 \\
P & Jasa Pendidikan & 1.70 & 0.85 & 0.32 & 0.28 \\
Q & Jasa Kesehatan dan Kegiatan Sosial & 1.42 & 0.95 & 0.36 & 0.68 \\
R,S, & Jasa lainnya & & & & \\
T,U & Jasa & 2.00 & 1.07 & 0.29 & 0.20 \\
\hline
\end{tabular}

Sumber: Hasil analisis LQ (data diolah dari BPS Sulsel)

Berdasarkan kriteria Nilai LQ dapat dilihat berbagai lapangan usaha/sektor yang memenuhi kategori sebagai sektor basis tiap kabupaten/kota adalah yang memiliki nilai LQ >1. Sektor basis tersebut selain mampu memenuhi kebutuhan dalam daerahnya juga dapat di ekspor 


\section{Jurnal Administrare: Jurnal Pemikiran Ilmiah dan Pendidikan Administrasi Perkantoran Vol. 5, No. 2, Juli - Desember 2018, Hal 85-98}

ke luar daerah. Kota Makassar dengan sektor basis terbanyak 12 sektor basis, Kab. Gowa, dengan 7 sektor basis, Kabupaten Takalar terdapat 4 sektor basis dan Kabupaten Maros dengan 3 sektor basis. Secara keseluruhan Makassar lebih banyak ditopang oleh sektor jasa. Kab Maros LQ tertinggi adalah Transportasi dan Pergudangan sebesar 8,9. Sedangkan Kab. Takalar LQ tertinggi adalah Pertanian, Kehutanan, dan Perikanan.

\section{b. Analisis Model Rasio Pertumbuhan(MRP) dan Overlay}

Identifikasi unggulan dari hasil overlay dibedakan dalam dua kriteria yaitu, hasil overlay yang menunjukkan ketiganya bernotasi positif, berarti sektor tersebut mempunyai pertumbuhan sektor ditingkat Provinsi Sulawesi Selatan tinggi, atau pertumbuhan sektor Kabupaten/kota di Kawasan Mminasata lebih tinggi dari Provinsi Sulawesi Selatan dan kontribusi sektor Kabupaten/kota Kawasan Maminasata lebih tinggi pula dari Provinsi Sulawesi Selatan. Artinya sektor tersebut mempunyai potensi daya saing kompetitif maupun komparatif yang lebih unggul dibandingkan dengan sektor yang sama pada tingkat Provinsi, dan di Provinsi sendiri sektor tersebut mempunyai prospek yang bagus.

Hasil overlay yang menunjukkan notasi positif pada RPs dan LQ berarti bahwa kegiatan sektoral di Kabupaten/kotadi Kawasan Maminasata lebih unggul dari kegiatan yang sama di Provinsi Sulawesi Selatan, baik dari sisi pertumbuhan maupun kontribusinya. Dengan kata lain bahwa sektor tersebut merupakan spesialisasi kegiatan ekonomi Kabupaten/kota di Kawasan Maminasata di Provinsi Sulawesi Selatan, namun di Provinsi sendiri sektor tersebut tidak mempunyai prospek yang bagus.

Hasil perhitungan MRP Kota Makassar setelah di overlay terdapat dua sektor yang komponennya bernotasi positif semua. Hal ini berarti bahwa ketiga sektor tersebut mempunyai potensi daya saing kompetitif dan komparatif di Kota Makassar yang serupa pada tingkat Provinsi Sulawesi Selatan. Sebaliknya, sektor dengan semua nilai komponennya bernotasi negatif berarti sektor ini tidak bukkan basis dan tidak memiliki keunggulan baik di Provinsi Sulsel ataupun di Kota Makassar. Dengan kata lain kebutuhan pada sektor ini masih dipasok dari daerah lain.

Sektor-sektor yang memiki nilai positif LQ, Rps dan RPs negatif, (+-+) yang berarti sektor ini lebih unggul dibandingkan dengan kegiatan sektoral yang sama di tingkat Provinsi, baik sisi pertumbuhannya maupun kontribusinya. Kegiatan sektoral tersebut juga mensupport sektor yang sama di daerah-daerah lain di kawasan Mamminasata.

\section{c. Analisis Tipologi Klassen}

Tipologi Klassen merupakan salah satu alat analisis ekonomi regional yang dapat digunakan untuk mengetahui klasifikasi sektor perekonomian wilayah. Analisis tipologi klassen digunakan dengan tujuan mengetahui klasifikasi sektor berdasarkan dua indikator utama, yaitu laju pertumbuhan ekonomi dan kontribusi Produk Domestik Regional Bruto (PDRB) dengan melihat posisi perekonomian suatu daerah dan memperhatikan perekonomian daerah referensi. 


\section{Tabel 2.}

Hasil Analisis Tipologi Klassen Kabupaten/Kota di Kawasan Maminasata Prov. Sulsel 2012-2016

\begin{tabular}{|c|c|c|c|c|c|}
\hline \multirow{2}{*}{ Kategori } & \multirow{2}{*}{ Lapangan Usaha } & \multicolumn{4}{|c|}{ Nilai Tip. Klassen PDRB 2012-2016 } \\
\hline & & Makassar & Gowa & Maros & Takalar \\
\hline A & Pertanian, Kehutanan, dan Perikanan & III & II & IV & I \\
\hline $\mathrm{B}$ & Pertambangan dan Penggalian & IV & III & I & III \\
\hline $\mathrm{C}$ & Industri Pengolahan & I & IV & I & IV \\
\hline $\mathrm{D}$ & Pengadaan Listrik, Gas & IV & I & IV & III \\
\hline $\mathrm{E}$ & Pengadaan Air & III & II & III & IV \\
\hline $\mathrm{F}$ & Konstruksi & I & III & III & IV \\
\hline G & $\begin{array}{l}\text { Perdagangan Besar dan Eceran, dan Reparasi } \\
\text { Mobil dan Sepeda Motor }\end{array}$ & I & III & IV & III \\
\hline $\mathrm{H}$ & Transportasi dan Pergudangan & III & III & I & IV \\
\hline I & Penyediaan Akomodasi dan Makan Minum & I & II & IV & IV \\
\hline $\mathrm{J}$ & Informasi dan Komunikasi & I & I & IV & IV \\
\hline $\mathrm{K}$ & Jasa Keuangan & I & III & IV & IV \\
\hline $\mathrm{L}$ & Real Estate & I & I & IV & I \\
\hline $\mathrm{M}, \mathrm{N}$ & Jasa Perusahaan & I & III & IV & IV \\
\hline $\mathrm{O}$ & $\begin{array}{l}\text { Administrasi Pemerintahan, Pertahanan dan } \\
\text { Jaminan Sosial Wajib }\end{array}$ & II & III & III & I \\
\hline $\mathrm{P}$ & Jasa Pendidikan & I & IV & IV & IV \\
\hline Q & Jasa Kesehatan dan Kegiatan Sosial & I & IV & IV & IV \\
\hline $\mathrm{R}, \mathrm{S}, \mathrm{T}, \mathrm{U}$ & Jasa lainnya & I & III & IV & IV \\
\hline
\end{tabular}

Sumber: Hasil Analisis data BPS

Secara akumulatif Kota Makassar nilai (TK) dominan ada di kuadran I (8 sektor/lapangan usha). Sedangkan Kabupaten lainnya masing-masing memilik 3 sektor di kuadran I. Kab. Gowa dominan berada di kuadran III (8 sektor), Kab. Maros dan Takalar dominan berada di kuadran IV (11 sektor).

\section{Pemetaan Kemiskinan dan Laju PDRB}

Pemetaan kemiskinan dan laju PDRB atau Pertumbuhan Ekonomi dimaksudkan untuk meninjau secara makro apakah pertumbuhan ekonomi Kabupaten/Kota di Wilayah Mamminasata cenderung bersifat inklusif atau tidak. Kemudian pemetaan ini akan dikorelasikan dengan sektor unggulan yang ada di wilayah ini. 


\section{Jurnal Administrare: Jurnal Pemikiran Ilmiah dan Pendidikan Administrasi Perkantoran Vol. 5, No. 2, Juli - Desember 2018, Hal 85-98}

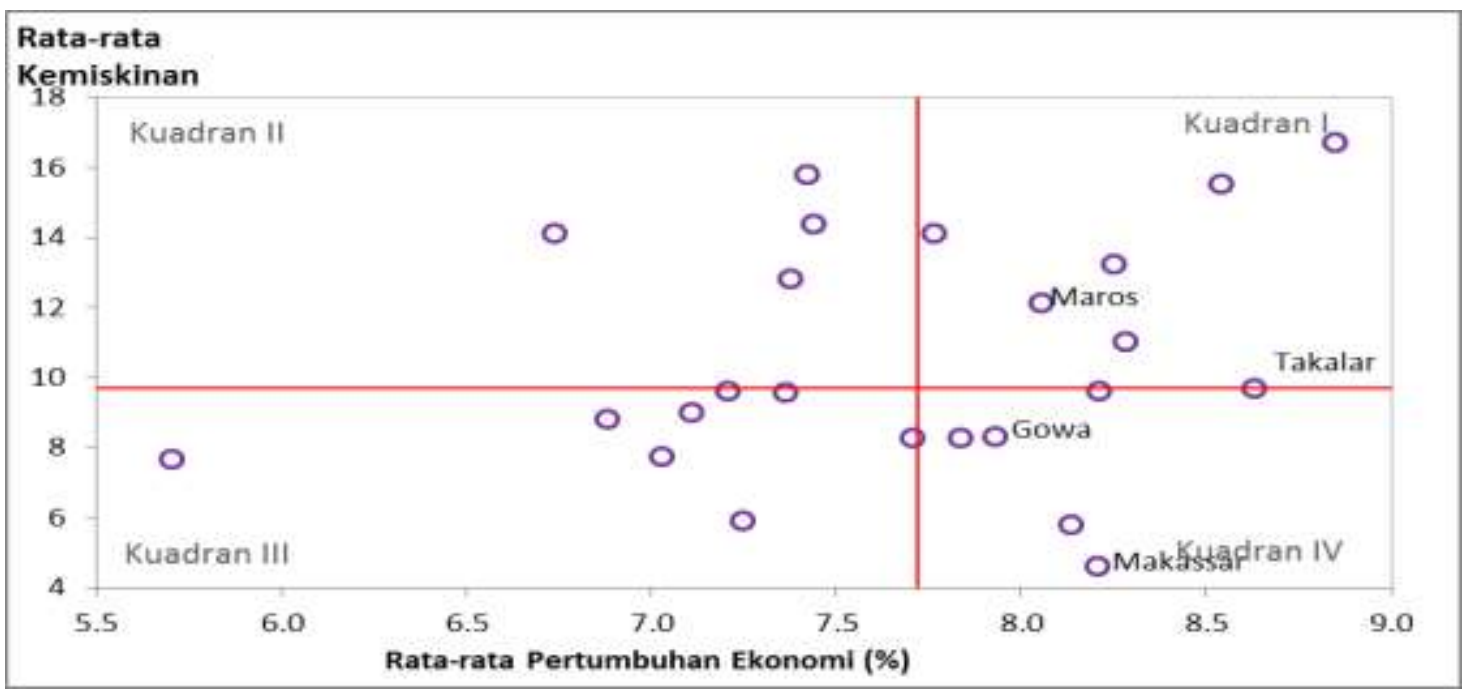

Kuadran I PE dan Rata-rata persentase kemiskinan Kab/kota lebih besar dari Prov. Sulsel

Kuadran II PE lebih rendah dan > Rata-rata persentase kemiskinan Kab/kota lebih besar dari Prov. Sulsel Kuadran III PE lebih rendah dan Rata-rata persentase kemiskinan Kab/Kota lebih rendah dari Prov. Sulsel

Kuadran IV PE lebih besar dan Rata-rata persentase kemiskinan KAb/Kota lebih rendah dari Prov. Sulsel

Gambar 2. Sebaran Kuadran Kab/Kota di Kawasan Maminasata Sulsel berdasarkan Rata-rata Pertumbuhan Ekonomi 2012-2016 dan Rata-rata Kemiskinan Tahun 2012 dan 2016

Nampak pada pemetaan gambar 2, bahwa secara rata-rata selama periode 2012-2016 Kota Makassar dan Kab. Gowa memiliki rata-rata jumlah penduduk miskin lebih rendah daripada Provinsi Sulawesi Selatan. Kabupaten Takalar berimpitan atau cenderung sama dengan provinsi Sulawesi Selatan. Sedangkan Kab. Maros di atas rata-rata kemiskinan Prov. Sulsel. Meskipun demikian, rata-rata pertumbuhan ekonomi Kab/kota yang ada di wilayah Mamminasata lebih tinggi daripada Prov. Sulawesi Selatan.

\section{Pembahasan}

Pengembangan wilayah Metropolitan Mamminasata dapat diarahkan sebagai pusat kegiatan nasional yang mendorong pertumbuhan kota-kota di sekitarnya sebagai sentra produksi wilayah pulau serta sebagai pusat orientasi pelayanan berskala internasional dan penggerak utama bagi Kawasan Timur Indonesia (Bappenas, 2014). Lazimnya pengembangan pusat pertumbuhan cenderung bersamaan dengan timbulnya ketimpangan pendapatan antar daerah dan kemiskinan.

Upaya pengembangan wilayah sebaiknya memerhatikan potensi unggulan tiap daerah yang ada di kawasan. Keseluruhan sektor ekonomi unggulan di dominasi oleh Kota Makassar dengan 11 sektor unggulan sedangkan Kabupaten lainnya maksimal 3 sektor unggulan. Selain itu konektivitas antara hulu-hilir belum terwujud di Kawasan Mamminasata. Berikut akan dibahas tiap Kabupaten/kota kaitannya dengan sektor ekonomi unggulan dan pemetaan kesmiskinan. 
Citra Ayni Kamaruddin, Syamsu Alam; Analisis Potensi Sektor Unggulan Pemetaan..... 95

\section{Sektor Unggulan dan Konektifitas antar Daerah di Wilayah Mamminasata.}

Kota Makassar sebagai pusat perekonomian khususnya industri pengolahan dan jasa. Kota Makassar memiliki 12 sektor unggulan atau sebagai sektor basis berdasarkan analisis LQ. Hasil LQ dan TK menunjukkan bahwa sektor Pertanian, Kehutanan, dan Perikanan bukan basis dan merupakan sektor yang tertekan. Sementara Kota Makassar dan Maros memiliki sektor industri pengolahan merupakan sektor basis dan unggulan. Fenomean ini menunjukkan adanya potensi terjadinya konektivitas dan kerjasama regional antar daerah yang memiliki sektor pertanian atau subsektor yang dapat mendukung sektor industri di Makassar. Meskipun demikian penelaahan lebih lanjut perihal komoditas apa yang diolah dalam industri. Tetapi indikasi ini menunjukkan adanya potensi untuk menjajaki kerjasama antar regional di wilayah Maminasata dan sekitarnya.

Kabupaten Gowa dan Takalar dan mungkin kabupaten lainnya di Sulsel dapat menyokong industri pengolahan di Kota Makassar Maros. Konektifitas antar sektoral atau antar komoditas akan meningkatkan nilai tambah dalam perekonomian. Lemahnya pengembangan kawasan industri di KTI menggiring perekonomian regional ke dalam perangkap nilai tambah (value-added trap). Hal ini tampak pada lemahnya kemampuan dunia usaha menyesuaikan dengan regulasi pembatasan ekspor komoditas non-olahan. . Sebagai contoh, kawasan industri Makassar (Kima) yang diorientasikan menjadi kawasan industri terintegrasi (integrated industrial estate) terbesar KTI hanya diisi oleh kegiatan perdagangan.

Beberapa tahun terakhir terjadi gejala deindustrialisasi yang ditandai oleh menurunnya peran sektor industri dalam perekonomian nasional. Pola pergeseran struktural seperti ini juga terjadi di sejumlah daerah di kawasan timur Indonesia (KTI), khususnya Kota Makassar dan Provinsi Sulawesi Selatan, yaitu dari daerah agraris langsung ke daerah perdagangan dan jasa. Makassar sebagai sentra bisnis utama KTI sangat didominasi oleh lapangan usaha perdagangan, hotel, restoran, sektor keuangan, dan sektor jasa lainnya. Meskepun tidak persis dengan gejala yang terjada secara nasional, karena Kota Makassar (Provinsi Sulsel) bukan daerah yang bertumbuh karena dorongan sektor industri.

Transformasi yang terjadi pada perekonomian nasional kita tidak berjalan secara normal, dari negara agraris ke negara industri, kemudian jasa. Transformasi yang terjadi bersifat langsung, dari negara agraris ke negara perdagangan dan jasa, tanpa melewati fase industrialisasi secara matang. Daerah-daerah di KTI khususnya Wilayah Mamminasata sejak awal tak memiliki platform pengembangan industri dan juga kawasan industri yang fokus membangun rantai pasokan global dengan industri negara lain. Argumentasi di atas terkonfirmasi dengan data statistik yang menunjukkan sektor perdagangan dan jasa yang unggul di kota Makassar tapi tidak di daerah lainnya yang ada di Kawasan Mamminasata sebagai Kawasan Strategis Nasional di KTI.

\section{Sektor Unggulan dan Potensi Reduksi Kemiskinan}

Secara aggregat penurunan kemiskinan di Wilayah Mamminasata cukup baik, namun ada paradoks. Dari $4 \mathrm{Kab} / \mathrm{Kota}$, hanya Kab. Takalar yang mengalami peningkatan kemiskinan sebesar 350 Jiwa selama periode penelitian. Padahal Kab. Takalar, satu-satunya Kab di Maminasata yang melangalami peningkatan Pertumbuhan Ekonomi dari 6,58 persen (2012) menjadi 9,52 persen (2016)atau meningkat sebesar 2,94 persen.Padahal secara teoretis Kenaikan Pertumbuhan ekonomi seharusnya menurunkan kemiskinan, demikian pula sebaliknya, namun 


\section{Jurnal Administrare: Jurnal Pemikiran Ilmiah dan Pendidikan Administrasi Perkantoran Vol. 5, No. 2, Juli - Desember 2018, Hal 85-98}

hal demikian tidak terjadi di Wilayah Mamminasata.Pengentasan kemiskinan di Kab. Takalar, sejauh ini tidak menampakkan hasil dan tidak disebabkan adanya tumpang tindih program di beberapa dinas, di antaranya, Dinas KB, Sosial, dan Kesehatan.

Keberhasilan Kota Makassar, Kab Gowa dan Maros menekan angka kemiskinan karena berbasis program. Penanggulangan kemiskinan yang dilaksanakan oleh Dinas Sosial Tenaga Kerja dan Transmigrasi serta Dinas Koperasi, Perindustrian dan Perdagangan Kabupaten Maros, melalui program penanggulangan kemiskinan yang meliputi program keluarga harapan $(\mathrm{PKH})$, program pemberdayaan fakir miskin (KUBE-FM) dan program pemberdayaan UMKM. Program yang serupa juga berjalan cukup baik di Kab. Gowa.

Kota Makassar secara khusus membuat regulasi strategi pengentasan kemiskinan. Peraturan Walikota Makassar Nomor 70 Tahun 2015 tentang Percepatan Penanggulangan Kemiskinan Kota Makassar Tahun 2015-2019. Dalam regulasi tersebut dirumuskan sejumlah rencana program pemenuhan hak dasar yaitu, 1) kecukupan dan mutu pangan; 2) perluasan pelayanan pendidikan; 3) perluasan akses layanan kesehatan; 4) akses layanan perumahan; 5) penyediaan air bersih; 6) perluasan akses tanah; 7) jaminan rasa aman; 8) partisipasi; 9) kesetaraan dan keadlan gender; dan 10) lingkungan hidup dan sumber daya alam.Sepintas dapat dilihat bahwa keseluruhan program masih berbasis pada peleyanan 'pemberian' atau masih terkesan 'menciptakan ketergantungan' belum pada bagaimana membangun kemandidiran masyarakat yang berbasis pada ruang spasial.

Hasil studi SMERU tentang kemiskinan spasial perkotaan serta hubungan antara perencanaan tata ruang kota dan upaya penanggulangan kemiskinan di Kota Makassar menunjukkan bahwa pemahaman para pemangku kepentingan, terutama Satuan Kerja Perangkat Daerah (SKPD), mengenai hubungan antara unsur perencanaan spasial dan upaya penanggulangan kemiskinan masih terbatas. Selain itu, upaya penanggulangan kemiskinan di Kota Makassar masih cenderung menitikberatkan pendekatan programatis dan cenderung berpijak pada mata anggaran, dan belum secara langsung menyentuh perencanaan spasial kota. Daerah-daerah di Wilayah Mamminasata belum menunjukkan upaya membangun konektivitas antar daerah dalam hal membangun dan memperkuat rantai produksi dan distribusi barang dan jasa.

\section{SIMPULAN}

Hasil analisis sektor unggulan secara konsistensi menunjukkan bahwa Kota Makassar secara konsisten unggul dan kompetitif pada 12 sektor ekonomi. Kota Makassar memiliki sektor yang cepat maju dan cepat tumbuh. Kabupaten Gowa dengan rata-rata bertumbuh maju tetapi tertekan atau juga disebut sebagai daerah berkembang cepat, dan merupakan daerah yang memiliki pertumbuhan ekonominya lebih rendah tetapi pendapatan perkapita lebih tinggi dibanding rata-rata pendapatan perkapita di Prov. Sulsel. Sedangkan Kab. Maros dan Takalar relatif tertinggal. Hal ini dapat dilihat dengan dominannya sekor ekonomi yang berada di kuadaran IV.

Berdasarkan alat analisis sektor unggulan Analisis Location Quotient (LQ), Analisis Model Rasio Pertumbuhan (MRP), Analisis Overlay, menunjukkan bahwa Kota Makassar memiliki 12 sektor unggulan, Kab. Gowa, 7 sektor unggulan, Kab. Maros 4 sektro unggulan, 
Citra Ayni Kamaruddin, Syamsu Alam; Analisis Potensi Sektor Unggulan Pemetaan.....|97

dan Kab. Takalar 3 sektor unggulan. Sedangkan hasil analisi Tipologi Klassen menunjukkan hanya Kota Makassar yang konsisten menjukkan 12 sektor yang unggul berada di kuadran I (sektor maju dan tumbuh cepat). Sedangkan Kabupaten lainnya hanya 3 sektor yang berada di kuadran I, sektor ekonomi lainnya bertumbuh tapi tertekan, ada juga yang potensial. Bahkan, Kab Maros dan Kab. Takalar memiliki 11 sektor yang masih tertinggal.

Kota Makassar dan Kab. Gowa memiliki rata-rata jumlah penduduk miskin lebih rendah daripada Provinsi Sulawesi Selatan. Kabupaten Takalar berhimpitan atau cenderung sama dengan Provinsi Sulawesi Selatan. Sedangkan Kab. Maros di atas rata-rata kemiskinan Prov. Sulsel. Meskipun demikian, rata-rata pertumbuhan ekonomi Kab/kota yang ada di wilayah Mamminasata lebih tinggi daripada Prov. Sulawesi Selatan.

Terdapat gejala paradoksal antara Laju PDRB dan kemiskinan. Secara aggregat kemiskinan di wilayah Mamminasata menurun selama periode penelitian. Pada Kota Makassar, Kab. Gowa, dan Kab. Maros, meskipun Laju pertumbuhannya menurun, jumlah warga miskinnya juga menurun. Sedangkan Kabupaten Takalar laju PDRBnya meningkat namun kemiskinannya juga meningkat.

\section{DAFTAR PUSTAKA}

Anwar, S., \& Sun, S. (2012). Trade liberalisation, market competition and wage inequality in China's manufacturing sector. Economic Modelling, 29(4), 1268-1277. https://doi.org/https://doi.org/10.1016/j.econmod.2012.03.013

Barberia, L. G., \& Biderman, C. (2010). Local economic development: Theory, evidence, and implications for policy in Brazil. Geoforum, 41(6), 951-962. https://doi.org/https://doi.org/10.1016/j.geoforum.2010.07.002

Chen, Q., Acey, C., \& Lara, J. J. (2015). Sustainable Futures for Linden Village: A model for increasing social capital and the quality of life in an urban neighborhood. Sustainable Cities and Society, 14, 359-373. https://doi.org/https://doi.org/10.1016/j.scs.2014.03.008

Hao, P., Sliuzas, R., \& Geertman, S. (2011). The development and redevelopment of urban villages in Shenzhen. Habitat International, 35(2), 214-224. https://doi.org/https://doi.org/10.1016/j.habitatint.2010.09.001

Johnson, N. D., \& Koyama, M. (2017). States and economic growth: Capacity and constraints. Explorations in Economic History, 64, 1-20. https://doi.org/https://doi.org/10.1016/j.eeh.2016.11.002

Lim, T. S. Y., Hassan, N., Ghaffarianhoseini, A., \& Daud, M. N. (2017). The relationship between satisfaction towards neighbourhood facilities and social trust in urban villages in $\begin{array}{llll}\text { Kuala } & \text { Lumpur. } & \text { Cities, } & \text { 85-94, }\end{array}$ https://doi.org/https://doi.org/10.1016/j.cities.2017.04.006

Mohanty, A., Gurpur, S., \& Beerannavar, C. R. (2014). Rethinking Inclusive Development: A 
98 Jurnal Administrare: Jurnal Pemikiran Ilmiah dan Pendidikan Administrasi Perkantoran Vol. 5, No. 2, Juli - Desember 2018, Hal 85-98

Human Rights Critique of South Asia. Procedia - Social and Behavioral Sciences, 157, 128-136. https://doi.org/https://doi.org/10.1016/j.sbspro.2014.11.016

Nisbett, M. (2017). Empowering the empowered? Slum tourism and the depoliticization of poverty. Geoforum, 85, 37-45. https://doi.org/https://doi.org/10.1016/j.geoforum.2017.07.007

Soyinka, O., \& Siu, K. W. M. (2017). Investigating Informal Settlement and Infrastructure Adequacy for Future Resilient Urban Center in Hong Kong, SAR. Procedia Engineering, 198, 84-98. https://doi.org/https://doi.org/10.1016/j.proeng.2017.07.075

Stan, S. (2015). Transnational healthcare practices of Romanian migrants in Ireland: Inequalities of access and the privatisation of healthcare services in Europe. Social Science \& Medicine, 124, 346-355. https://doi.org/https://doi.org/10.1016/j.socscimed.2014.04.013

Timár, J., \& Velkey, G. (2016). The relevance of the political economic approach: The interpretations of the rural in the migration decision of young women and men in an economically backward region. Journal of Rural Studies, 43, 311-322. https://doi.org/https://doi.org/10.1016/j.jrurstud.2015.11.012

Wu, X., \& Song, X. (2014). Ethnic Stratification amid China's Economic Transition: Evidence from the Xinjiang Uyghur Autonomous Region. Social Science Research, 44, 158-172. https://doi.org/https://doi.org/10.1016/j.ssresearch.2013.12.002

Zaman, K., \& Khilji, B. A. (2013). RETRACTED: The relationship between growth and poverty in forecasting framework: Pakistan's future in the year 2035. Economic Modelling, 30, 468-491. https://doi.org/https://doi.org/10.1016/j.econmod.2012.07.021 